\title{
Mengungkap Seni Bermatematika dalam Pembelajaran
}

\author{
Zubaidah Amir \\ Program Studi Pendidikan Matematika Fakultas Tarbiyah dan \\ Keguruan, UIN Sultan Syarif Kasim Riau
}

Email: zubaidah_mz@yahoo.com

\begin{abstract}
ABSTRAK. Matematika merupakan salah satu pelajaran wajib yang diajarkan disekolah. Matematika sekolah diberikan bertujuan untuk membantu siswa mempersiapkan diri agar sanggup menghadapi perubahan keadaan di dalam kehidupan dan di dunia yang selalu berkembang, melalui latihan bertindak atas dasar pemikiran secara logis, rasional dan kritis. Matematika sekolah di ajarkan juga bertujuan untuk mempersiapkan peserta didik agar dapat menggunakan matematika dan pola pikir matematika dalam kehidupan sehari-hari dan dalam mempelajari ilmu pengetahuan. Tujuan pendidikan matematika di sekolah lebih ditekankan pada penataan nalar, dasar pembentuk sikap, serta keterampilan dalam penerapan matematika. Untuk tercapainya tujuan tersebut, matematika itu dibutuhkan berbagai pendekatan dengan memasukkan unsur seni dalam pembelajaran. Tujuan penulisan makalah ini adalah agar pembelajaran matematika dapat menggunakan pendekatan unsur seni. Matematika itu adalah seni. Di dalam seni terlihat unsur-unsur keindahan, keteraturan dan keterurutan. Begitu pula dalam matematika yang memiliki unsur-unsur keteraturan, keterurutan dan ketetapan/konsisten. Pembelajaran matematika dengan memasukan unsur seni dapat dilakukan dengan berbagai cara, seperti mengungkap matematika indah, bercerita matematika, teka-teki matematika, permainan matematika. Unsur seni dalam pembelajaran matematika dapat meningkatkan minat anak terhadap pelajaran matematika.
\end{abstract}

Kata kunci : seni matematika, bermain matematika, teka-teki matematika. 


\section{PENDAHULUAN}

Tidak dipungkiri bahwa matematika merupakan pelajaran yang sangat penting. Hal ini diisyaratkan oleh pemerintah bahwa matematika menjadi pelajaran wajib di sekolah, mulai dari pendidikan dasar hingga pendidikan tinggi. Matematika merupakan salah satu pelajaran yang diajarkan disekolah. Matematika sekolah diberikan bertujuan untuk membantu siswa mempersiapkan diri agar sanggup menghadapi perubahan keadaan di dalam kehidupan dan di dunia yang selalu berkembang, melalui latihan bertindak atas dasar pemikiran secara logis, rasional dan kritis (Tim MKPBM, 2001). Sriyanto (2007) menyatakan matematika sekolah di ajarkan juga bertujuan untuk mempersiapkan peserta didik agar dapat menggunakan matematika dan pola pikir matematika dalam kehidupan sehari-hari dan dalam mempelajari ilmu pengetahuan. Tujuan pendidikan matematika di sekolah lebih ditekankan pada penataan nalar, dasar pembentuk sikap, serta keterampilan dalam penerapan matematika (Sriyanto, 2007). Ada pepatah, "tak kenal maka tak sayang". Pepatah ini kiranya juga berlaku dalam mempelajari matematika. Seseorang tidak bisa belajar matematika dengan baik kalau ia tidak menyukai, atau paling tidak punya minat terhadap matematika. Dan seseorang tak mungkin menyukai matematika, kalau dia tidak mengenal dengan baik apa itu sesungguhnya matematika. Begitu pun bagi siswa dalam pembelajaran matematika. Siswa tidak bisa belajar matematika dengan baik kalau ia tidak menyukai atau paling tidak punya minat terhadap matematika. Siswa tidak mungkin menyukai matematika kalau ia tidak mengenal dengan baik apa itu sesungguhnya matematika.

Sering kali memang matematika yang hadir di depan kita khususnya siswa dalam pembelajaran matematika adalah matematika dikenal hanyalah kumpulan rumus, abstrak, teoritis dan kering. Tapi apakah matematika hanya melulu rumus yang teoritis sekaligus abstrak? Tidak! Sebenarnya ada banyak sisi menarik dalam matematika yang mungkin selama ini belum dikenal oleh siswa, dan sayangnya jarang dihadirkan, jarang disentuh, bahkan tidak pernah dihadirkan dalam pembelajaran di kelas.

Tidak dipungkiri lagi bahwa di masyarakat beredar ungkapan "matematika itu menyeramkan" ini yang membuat anak-anak menjadi apatis, takut pada matematika, apalagi kemauan untuk mengerjakan soal-soal matematika. Pada dasarnya sulit atau tidaknya matematika sebenarnya tergantung pada cara pandang dan penilian masing-masing individu. Hanya masalahnya selama ini matematika terlanjur di cap sebagai mata pelajaran sulit, lebih karena pengalaman yang tidak menyenangkan banyak orang ketika belajar matematika. Dan repotnya pengalaman tersebut ditularkan 
kepada orang lain, sehingga orang yang akan belajar matematika turut mempersepsikan matematika sebagai bidang studi yang sulit. Hal ini secara tidak langsung akan mempengaruhi minat seseorang dalam mempelajari matematika.

Dalam proses pembelajaran matematika di kelas, peranan seorang guru sangat menentukan minat belajar seorang siswa. Jika cara guru menyampaikan pembelajaran matematika tidak menyenangkan, maka akan memberikan dampak yang kurang baik bagi siswa. Namun jika guru mampu menyajikan pembelajaran matematika dalam bentuk yang menarik, indah dan menyenangkan, maka akan mendorong minat siswa dalam mempelajari matematika. Karena pada dasarnya minat sangat mempengaruhi terhadap proses dan hasil belajar. Kualitas minat belajar akan seiring dengan kualitas hasil belajar. Semakin tinggi minat belajar siswa, maka akan semakin bagus pula hasil belajarnya (Sardiman, 2006) Nah, pertanyaan sekarang muncul, banagaimanakah cara menyajikan pelajaran dalam bentuk menarik, indah dan menyenangkan, sehingga mampu mendorong minat belajar matematika siswa?

Menurut Hudojo (1988), memecahkan minat merupakan jenis motivasi yang sering kali dikaitkan dengan tingkah laku berikut yaitu: seseorang ingin sesuatu yang lebih banyak, orang itu secara sukarela mencarinya dan bahkan mengulanginya, ia tetap seperti itu untuk suatu periode waktu dan mungkin ia akan membelikan rekomendasi kepada orang lain. Jadi meningkatkan minat siswa terhadap pelajaran matematika adalah usaha agar siswa secara sukarela mempunyai keinginan yang tinggi untuk mempelajari matematika. Guru merupakan faktor yang penting dalam menarik minat siswa terhadap pelajaran matematika. Menurut Soedjadi, untuk dapat meningkat minat siswa terhadap matematika terlebih dahulu harus bahwa guru matematikanya juga mempunyai minat yang tinggi terhadap matematika (Soejadi, 1992).

Dari uraian diatas, faktor minat guru terhadap matematika menjadi salah satu penentu dalam meningkatkan minat belajar matematika siswa. Seorang guru tidak akan memiliki minat yang tinggi terhadap matematika, jika guru tdak mengenal matematika dengan baik. Dalam hal ini mengenal matematika dimaksud adalah mengenal sisi keindahan dan seni bermatematika. Jika guru mengenal sisi seni dalam bermatematika, maka guru dapat menyajikan matematika tersebut dengan indah di kelasnya.

Johnson dan Rising (1972), mengatakan bahwa matematika adalah bahasa, yang menggunakan istilah yang didefinisikan dengan cermat, jelas dan akurat. Matematika adalah ilmu tentang pola, seni keindahannya terdapat 
pada keterurutan dan keharmonisannya (Faribarca, 2012). Kutipan di atas terlihat sangat menarik dan mengarah kepada pengertian bahwa matematika adalah bahasa dan memiliki seni atau keindahan.

Seni belajar mengajar matematika dalam makalah ini diartikan sebagai bentuk matematika dan persoalan matematika yang ditinjau dari sisi lain, namun tetap dalam konteks matematika, soal-soal matematika yang penuh seni dan keindahan. Seni matematika ini menuntut kreativitas guru dalam mengembangkan wawasan yang berkaitan dengan matematika atau persoalan yang berhubungan dengan matematika. Sehingga dapat menunjang penanaman konsep-konsep matematika yang sudah diberikan dan dapat membuat siswa menyenangi pelajaran matematika serta dapat melatih siswa untuk berpikir matematik seperti pada tujuan kurikulum matematika.

Sebagai contoh, sebelum guru mengakhiri pelajarannya dapat memberikan permainan matematika teka teki bilangan. Suruhlah seorang siswa memilih sebuah bilangan yang terdiri dari dua angka. Minta ia merahasiakannya. Suruhlah ia mengalikan angka puluhannya dengan 2, hasilnya kurangi dengan 3, lalu kalikan dengan 5, dan akhirnya tambahkan dengan angka satuan dari bilangan asal. Mintalah hasil perhitungan tersebut. Dari hasil perhitugan itu, kita dapat menerka lambang bilangan yang dipilih tadi oleh si anak. Yaitu dengan cara: Hasil perhitungan $+15=$ bilangan asal yang dipilih dan dirahasiakan oleh siswa tersebut (Ruseffendi, 2010).

Dari uraian di atas, penulis tertarik untuk mengupas beberapa contoh keindahan matematika dan seni bermatematika dalam proses pembelajaran matematika. Dalam tulisan ini, penulis tidak membahas secara mendalam mengenai metode pengajaran matematika maupun metode pengajaran bermain matematika. Dalam makalah ini juga tidak dibatasi untuk jenjang pendidikan, artinya unsur seni dalam pengajaran matematika dapat dilakukan di SD, SMP, maupun SMU.

\section{SENI KEINDAHAN MATEMATIKA}

Matematika ternyata menyimpan keindahan. Bagaimana mengungkap keindahan matematika?. Materi ini disajikan dengan tujuan agar matematika kita lebih memahami makna matematika sebagai sebuah ilmu yang dikenal sebagai pelayan ilmu pengetahuan (servant of sciences), ratu ilmu pengetahuan (queen of sciences), bahasa ilmu pengetahuan (language of sciences), yang hidup untuk menghidupkan ilmu-ilmu lain, dan merupakan salah satu dari ilmu-ilmu dasar (basic sciences).

Banyak definisi mengenai matematika, tergantung kepada latar belakang dan pemahaman pembuat definisi sendiri. Disamping itu, banyak 
matematikawan yang mendefinisikan bahwa matematika adalah ilmu yang mempelajari mengenai teorema-teorema dan sistem aksiomatis. Definisi ini sedikit problematik karena belum mencakup topik-topik matematika yang bersifat eksploratif dan eksperimen baik yang dikerjakan secara manual oleh matematikawan sebelum abad ke-20, maupun yang dilakukan dengan komputer oleh matematikawan mulai abad ke-20.

Menurut Soehakso (2012), profesor Matematika pertama di Indonesia, Matematika mempunyai pola yang sangat menarik, begitu menariknya, beliau sering mengatakan bahwa Matematika bagaikan gadis tercantik di seluruh dunia. Rupanya setelah lama kita mempelajari Matematika, yang dimaksud cantik adalah polanya termasuk pola abstraknya, sedang yang dimaksud di seluruh dunia adalah kebaharuan Matematika bersifat universal di seluruh dunia, misalnya penemuan rumus abc dalam penyelesaian persamaan kuadrat dan penemuan rumus kosinus oleh Al Khawarizmi berlaku untuk seluruh dunia (Widodo, 2012) . Begitu pula semua penemuan penelitian misalnya disertasi doktor Matematika, unsur kebaharuannya berlaku secara universal di manapun.

Metematika merupakan disiplin ilmu otonom, dapat berdiri sendiri, satu dari ilmu-ilmu pengetahuan yang mempunyai kekuatan kreatif akal manusia yang paling jelas. Matematika memainkan peran fundamental dalam ilmu pengetahuan modern, mempunyai pengaruh kuat baginya dan dipengaruhi pula olehnya dalam berbagai cara. Dalam matematika ada dua konsep yang seringkali menjadi perbedaan dalam matematika, yaitu matematika murni (pure mathematics) dan matematika terapan (applied mathematics). Hendaknya kita memandang keduanya sebagai satu keping mata uang, sama, hanya berbeda cara pandang dari kedua sisinya, dan tidak perlu dipertentangkan, bahkan saling menguatkan.

Dari sudut pandang ilmu murni, matematika dipandang sebagai seni dan kreatifitas yang dimainkan oleh fikiran manusia. Matematika merupakan kreatifitas yang mengekspresikan keindahan bentuk aksioma, teorema, relasi logika, relasi numerik, yang semuanya menarik bagi penelitinya karena kesempurnaan logikanya, sehingga menjadikannya sebuah ilmu yang mendorong peningkatan kapasitas manusia. Karena kesempurnaan logika inilah, maka dalam matematika tidak ada kontradiksi tentang nilai kebenaran di dalamnya. Tokoh matematika seperti Pythagoras, Plato sampai Gauss melihat bahwa matematika dipandang sebagai sistem yang teratur dan lebih sempurna daripada dunia nyata dalam kehidupan sehari-hari.

Dari sisi aplikasi, matematika dapat mengungkap fenomena-fenomena alam, masalah kehidupan sehari-hari, dan masalah dalam ilmu pengetahuan 
dan teknologi. Dalam empat abad terakhir kepentingan praktis matematika dalam ilmu pengetahuan dan teknologi (IPTEK) tak terbantahkan lagi, karena sebagian besar ilmuwan sangat menyadari makna matematika sebagai ilmu alat, sebagai pelayan, dan sebagai bahasa bagi ilmu-ilmu lainnya. Oleh karenanya diperbagai universitas di dunia, matematika dipandang mempunyai peran yang sangat penting pada hampir sетиa bidang IPTEK, seperti ilmu fisika, kimia, biologi, farmasi, ekonomi, ilmu komputer, ilmuilmu rekayasa, ilmu-ilmu sosial, dan lain-lain.

Matematika sebagai bagian integral dari kebudayaan manusia mengandung dimensi kemanusiaan dan memiliki keindahan tersendiri. Keindahan biasanya dijelaskan melalui unsur-unsurnya seperti keserasian, keteraturan, keselarasan, keseimbangan, keseragaman, keutuhan dan sebagainya (Sriyanto, 2007). Widodo (2012) mengemukakan seorang Matematikawan Amerika Serikat mengatakan bahwa matematikawan bagaikan pelukis atau pembuat puisi, semuanya pembuat pola. Berikut contoh puisi matematika yang dibuat oleh Mutiara Hikmah, siswa SD Kelas IV SDN 08 Talang Jawa Tanjung Enim, pada kongres IndoMS 2008, yang membentuk pola menarik dan cantik (Widodo, 2012).

\section{RUMAH SEGI EMPAT :}

Di suatu simpang empat

Di pemukiman yang rapat

Terdapat sebuah rumah segi empat

Pintu dan jendelanya berwarna coklat

Di halaman trapesium hijau nanluas

Tumbuh lingkaran tanaman hias

Ada juga tanaman pisang, rambutan dan nanas

Diameter kebahagiaan terukir disebuah senyuman puas

Dalam rumah sederhana segi empat

Terdapat kamar bujur sangkar sebanyak empat

Keliling kamar kutambahkan setiap sisinya yang

berjumlah empat

Luas kamarku adalah hasil dari sisi kuadrat

Genting tanah liat menghiasi atap rumahku 
Tampak bangunan segitiga dari depan rumahku Keliling segitiga tambahkan setiap sisi atap rumahku Luas segitiga alas kali tinggi dibagi dua sisi atap rumahku Terdapat sebuah lukisan pemandangan yang terpanjang Di ruang tamuku yang berbentuk persegi panjang Bila ditambahkan setiap sisi ku dapatkan keliling persegi panjang

Luas persegi panjang hasil perkalian lebar dan panjang Wahai kawan akulah penghuni rumah segi empat Aku ingin belajar dengan cermat dan giat Agar memperoleh ilmu yang bermanfaat Dan menjadi orang berguna di masyarakat.

Selain mengandung unsur-unsur keindahan pada umumnya, keindahan matematika juga memuat unsur-unsur yang khas, misalnya terbuktinya suatu teorema yang sudah lama diprediksikan kebenarannya, terungkapnya suatu hubungan tak terduga antara konsep yang tampaknya tak berkaitan sama sekali, tampilan grafis yang menakjubkan dari suatu himpunan titik-titik dengan sifat-sifat tertentu dan sebagainya.

Grafik himpunan itu juga divisualkan akan tampak sangat indah dan mengagumkan. Kalau kita melihat grafiknya, mungkin kita tidak percaya bahwa itu suatu himpunan.

Sekarang ini sudah banyak program komputer yang dapat membantu memudahkan kita dalam mempelajari matematika. Grafik fungsi trigonometri, irisan benda-benda ruang dapat dengan mudah kita lihat tampilan visualnya. Dengan bantuan komputer grafik fungsi berderajat banyak yang semula sulit untuk dibayangkan, sekarang dengan mudah dapat dilihattampilannya di layar komputer. Berikut ini beberapa contoh tampilan visual grafik dari fractal.
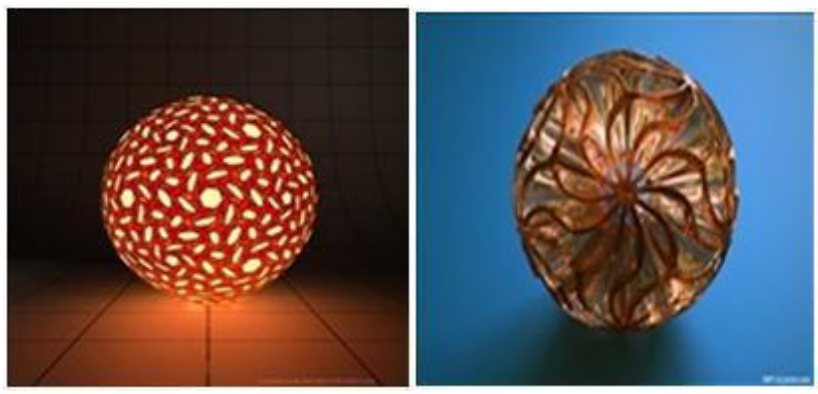

66 Suska Journal of Mathematics Education Vol.1, No.1, 2015 


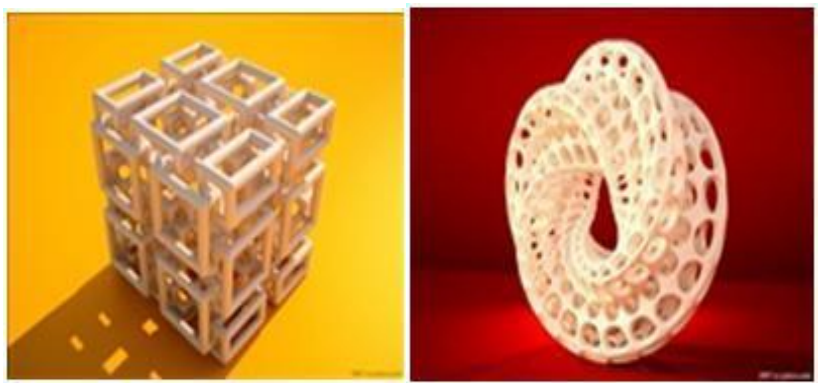

Gambar 1. Fractal

Setelah kita lihat tak dapat dibantah keindahannya."Wou, indah bukan?" (Dimas, 2012).

Masih banyak contoh lain dalam konsep matematika yang mempunyai keindahan. Berkaitan dengan nilai seni ini, Soedjadi (1994) mengemukakan bahwa dalam pengajaran matematika sekolah dapat diorientasikan kepada nilai-nilai yang terkandung dalam matematika itu antara lain nilai estetika, yaitu nilai yang berkaitan dengan "keindahan" dan nilai keindahan atau rangsangan, yaitu nilai yang berkaitan dengan daya pembangkit rasa indah.

Apabila guru dapat menyampaikannya kepada anak didiknya, bahwa matematika itu penuh seni dan nilai keindahan, tentu akan menimbulkan rasa senang dan motivasi yang kuat untuk ingin mempelajari matematika. Di samping itu juga menanamkan kesan bahwa matematika itu adalah pelajaran tidak sulit. Tapi dibalik ke'angker'annya ternyata Matematika menyimpan sebuah keindahan. Perhatikan pola-pola perhitungan matematika berikut ini :

$$
\begin{aligned}
1 \times 8+1 & =9 \\
12 \times 8+2 & =98 \\
123 \times 8+3 & =987 \\
1234 \times 8+4 & =9876 \\
12345 \times 8+5 & =98765 \\
123456 \times 8+6 & =987654 \\
1234567 \times 8+7 & =9876543 \\
12345678 \times 8+8 & =98765432 \\
123456789 \times 8+9 & =987654321 \\
1 \times 9+2 & =11 \\
12 \times 9+3 & =111 \\
123 \times 9+4 & =1111 \\
1234 \times 9+5 & =11111
\end{aligned}
$$




$$
\begin{aligned}
12345 \times 9+6 & =11111 \\
123456 \times 9+7 & =111111 \\
1234567 \times 9+8 & =1111111 \\
12345678 \times 9+9 & =11111111 \\
123456789 \times 9+10 & =111111111 \\
9 \times 9+7 & =88 \\
98 \times 9+6 & =888 \\
987 \times 9+5 & =8888 \\
9876 \times 9+4 & =88888 \\
98765 \times 9+3 & =888888 \\
987654 \times 9+2 & =8888888 \\
9876543 \times 9+1 & =88888888 \\
98765432 \times 9+0 & =888888888 \\
(0 \times 9)+8 & =8 \\
(9 \times 9)+7 & =88 \\
(98 \times 9)+6 & =888 \\
(987 \times 9)+5 & =8888 \\
(9876 \times 9)+4 & =88888 \\
(98765 \times 9)+3 & =888888 \\
(987654 \times 9)+2 & =8888888 \\
(9876543 \times 9)+1 & =88888888 \\
(98765432 \times 9)+0 & =888888888 \\
(987654321 \times 9)-1 & =8888888888 \\
37 \times 37 & =111 \\
6 \times 37 & =222 \\
9 \times 37 & =333 \\
12 \times 37 & =444 \\
15 \times 37 & =555 \\
18 \times 37 & =666 \\
21 \times 37 & =777 \\
24 \times 37 & =888 \\
27 \times 37 & =999 \\
12 \times 8+1 & =9 \\
& =98 \\
98 &
\end{aligned}
$$




$$
\begin{aligned}
123 \times 8+3 & =987 \\
1234 \times 8+4 & =9876 \\
12345 \times 8+5 & =98765 \\
123456 \times 8+6 & =987654 \\
1234567 \times 8+7 & =9876543 \\
12345678 \times 8+8 & =98765432 \\
123456789 \times 8+9 & =987654321 \\
3^{2}+4^{2} & =5^{2} \\
10^{2}+11^{2}+12^{2} & =13^{2}+14^{2} \\
21^{2}+22^{2}+23^{2}+24^{2} & =25^{2}+26^{2}+27^{2} \\
36^{2}+37^{2}+38^{2}+39^{2}+40^{2} & =41^{2}+42^{2}+43^{2}+44^{2}
\end{aligned}
$$

Matematika adalah sebuah Kebenaran. Tidak akan ada yang bisa menyangkal hasilnya. Juga salah satu keindahan yang datang dari Tuhan. Dari puisi matematika, visualisasi grafik dan pola-pola bilangan di atas terlihat jelas, bahwa matematika memiliki sifat unsur keserasian, keteraturan, keselarasan, keseimbangan, keseragaman, dan keutuhan, sehingga memenuhi sifat keindahan. Benar adanya matematika suatu hal yang indah. Penyajian keindahan ini dapat disampaikan pada siswa pada saat memberikan materi pelajaran Barisan Bilangan (Pola Bilangan), untuk siswa SMP maupun SMU. Untuk puisi diatas dapat diberikan pada siswa sekolah dasar. Sedangkan untuk visualisasi gambar diatas merupakan materi fungsi yang dipelajari baik di SMP maupun di SMA. Kemampuan yang dapat dicapai adalah berpikir kritis, efisien dan cermat.

\section{BERMAIN MATEMATIKA}

Apabila suatu pekerjaan atau persoalan jika dihadapai dengan sedih, takut, tegang atau sejenisnya sedikit banyak akan menyulitkan menyelesaikan persoalan tersebut. Begitu pula dalam pelajaran matematika apabila dihadapi dengan rasa takut, cemas, tegang, atau sejenisnya maka anak akan mengalami kesulitan dalam mempelajarinya. Oleh karena itu pelajaran matematika harus bisa disajikan dalam bentuk yang menarik perhatian anak agar bisa menyenanginya.

Salah satu teori yang membahas mengenai bermain matematika ini yaitu teori Dienes. Dienes mengembangkan teorinya agar matematika menjadi lebih menarik dan mudah dipelajari dan menekankan betapa pentingnya memanipulasi obyek-obyek matematika yang abstrak ke konkrit melalui bentuk permainan matematika. Bermain matematika di sini 
merupakan suatu penyajian pelajaran yang bisa membuat siswa tertarik, karena materi yang diberikan kebanyakan bersifat menyenangkan dan dalam suasana yang gembira serta membuat anak ingin tahu tentang sesuatu yang ditanyakan. Dengan demikian anak akan terlatih dalam berpikir matematika, di samping itu juga melalui bermain matematika dapat menanamkan konsepkonsep matematika.

Senada dengan ini Soedjadi mengatakan bahwa "Sesuai dengan perkembangan kognitif peserta didik, penataan nalar tidak harus dilakukan dengan suasana yang serius. Permainan matematika dapat menjadi wahana penataan nalar anak tanpa harus selalu 'tegang' dalam melakukannya" (Soejadi, 1994). Hal ini mengandung makna bahwa bermain matematika perlu diberikan kepada peserta didik, agar siswa tidak bosan dengan pelajaran matematika yang ba nyak membahas teori, konsep, dalil, definisi dan mengerjakan soal-soal yang berbentuk angka angka maupun bangun-bangun geometri. Dalam pembahasan ini bermain matematika dibagi menjadi tiga bagian yaitu: berbentuk cerita, teka-teki matematika, dan permainan matematika.

\section{Berbentuk Cerita}

Persoalan matematika yang berbentuk cerita ini dapat berupa aplikasi matematika dalam kehidupan sehari-hari. Seperti pada soal-soal persamaan tersamar, ataupun berbentuk soal cerita yang lucu tapi masuk akal jika ditinjau dari segi matematikanya. Dalam bentuk soal ini siswa di tuntun untuk berpikir secara sistematik, logis, rasional, eksak, kritis seperti halnya dalam matematika. Berikut beberapa contoh persoalan yang berbentuk cerita (Somakin, 1997) :

1) Seorang bapak dengan berat $70 \mathrm{~kg}$ dan dua orang anaknya akan menyeberangi sebuah sungai dengan sebuah perahu yang memiliki daya muat hanya $80 \mathrm{~kg}$. Sedangkan berat kedua anaknya masing-masing $35 \mathrm{~kg}$ dan $40 \mathrm{~kg}$. Bapak dan kedua anaknya dapat mendayung. Bagaimana caranya mereka dapat menyeberang?

Contoh di atas dapat dikaitkan dengan materi Teori Kemungkinan. Soal cerita ini dapat diberikan pada anak SD kelas 5 dan 6. Keterampilan yang dapat dicapai melalui soal ini berupa penalaran, berpikir logis dan kritis.

2) Suatu hari, seorang peternak sapi yang kaya di sebuah desa meninggal dunia. Dalam surat wasiatnya, ke-23 ekor sepinya diwariskan pada tiga orang anak-nya Pembagiannya, si sulung mendapat seperdua bagian, anak kedua memperoleh sepertiga bagian, dan si bungsu menerima seperdelapam bagian. Tetapi syarat yang tercantum dalam surat wasiat 
cukup berat. Dalam pembagian harta tersebut, almarhum tak mau ada sapi yang terpotong. Bagaimana caranya yang harus dilakukan oleh para ahli waris, supaya pembagian tetap adil tanpa menyalahi pesan ayahnya?

Contoh tersebut dapat dikaitkan dengan materi Soal Cerita untuk siswa SD kelas 5 dan 6, dapat juga diberikan untuk siswa SMP. Penalaran yang dapat dilakukan yaitu penalaran logis dan kritis (Somakin, 1997).

\section{Teka-teki Matematika}

Teka-teki matematika pada dasarnya hampir sama dengan bentuk cerita. Tetapi dalam teka-teki ini beraipat tebak-tebakan yang dilakukan oleh sepasang pemain atau lebih. Dalam persoalan teka-teki akan membuat anak menjadi atau rasa ingin tahu, kecuali si anak sudah tahu jawabannya. Suasanalah yang menyebabkan orang secara sukarela mau diajak bermain teka-telci/tebak-tebakan matematika. Apabila guru seringkali memberikan persoalan ini tentu akan terjalin hubungan yang tidak kaku antara guru dengan anak didik di samping itu juga dapat selalu melatih siswa berpikir . Berikut ini adalah contoh teka-teki :

1) Ada lima ekor burung hinggap di atas rumah, dua ekor kena tembak, adaberapa ekor burung yang tinggal di atas rumah itu?

2) Ada bebek sedang berjalan beruntun. Dua ekor bebek ada di depan yang satu, dua ekor bebek ada dibelakang yang satu, sedang seekor ada di tengah. Berapa ekor bebek paling sedikit? (jawab: 3 ekor).

3) Mintalah seseorang untuk memikirkan dua pasang bilangan yang lambang bilangannya masing-masing tidak lebih dari 2 angka. Misalnya nomor sepatu dan usia, tanggal dan bulan lahir, dan sebagainya. Lakukan perhitungan sebagai berikut: bilangan pertama dikalikan dengan 2 hasilnya ditambah 3, hasilnya kalikan 5, tambah lagi 4, lalu kalikan dengan 10, dan terakhir tambahkan bilangan kedua. Suruhlah ia memberi tahu hasil perhitungannya.

Dengan mengurangkan 190 kepada hasil perhitungan si anak tadi, kita dapat menyebutkan kedua bilangan yang dirahasiakan itu. Andai selisih antara hasil perhitungan anak dengan 190 adalah 2435, maka bilangan pertama ialah 24 dan bilangan kedua 35.Contoh ini dapat diberikan pada siswa sekolah dasar maupun SMP, maupun SMA. Hal ini mengasah penalaran, berpikir cermat dan kritis siswa.

\section{Permainan Matematika}

Permainan matematika disini adalah suatu kegiatan yang menyenangkan yang dapat menunjang tujuan instruksional dalam pengajaran matematika bagi aspek kognitif, afektif maupun psikomotorik. Dienes dan 
Piaget dalam Hudojo (1988) menyatakan ada beberapa bentuk permainan matematika yang disesuaikan dengan tahap perkembangan intelektualnya, yaitu antara lain: permainan bebas (fiee play) dan permainan yang menggunakan aturan (Games). Permainan bebas adalah tahap belajar konsep yang terdiri dari aktivitas yang tidak terstruktur dan tidak diarahkan yang memungkinkan peserta didik mengadakan eksperimen dan memanipulasi benda-benda konkrit dan abstrak dari unsur-unsur konsep yang dipelajari itu.

Contoh dari bebas ini antara lain:

1) Permainan dengan prinsip Geometri di sekolah dasar apat diaplikasikan pada pengukran tinggi sebuah pohon yang tinggi yang berdiri tegak diatas permukaan tanah. Kali ini tidak menggunakan klinomoter, namun dengan menggunakan bayangan dari pohon itu sendiri.

2) Anak-anak dapat diminta untuk membawa tanah liat ke sekolah. Mereka dapat melakukan penulisan lambang bilangan seperti yang pernah dilakukan oleh bangsa babylonia zaman dulu. Tanah liat yang sudah ditulis kemudian dikeringkan atau dibakar. (lihat sistem numerasi Babylonia). Permaianan ini mengajak siswa mengenal sejarah matematika untuk menghargai nilai-nilai perkembangan matematika, mengasah sikap ulet, kerja keras.

3) Permainan Tangram

Tangram adalah sebuah bujur sangkar yang dipotong menjadi tujuh bagian bangun-bangun geometri yang terdiri dari dua buah segitiga samakaki kecil dan sebuah jajar genjang (gambar 2). Unsur seni dalam permainan tangram ini adalah dari tujuh bangun geometri itu dapat dibentuk menjadi banyak bangunan yang indah. Dalam kotak-kritik tangram ini siswa tentu akan aktif karena siswa merasa dan ingin membentuk semua bentuk yang dapat dibentuk. Hal ini jelas membantu siswa dalam menata berpikir matematik dan kemampuan penalaran. dikaitkan dengan materi geometri bidang datar. Untuk anak SD cukup sebagai alat permainan Saja. sedangkan untuk siswa SMP bisa dilanjutkan dengan membuat alat tangram (bahan praktek). kemampuan yang dapat dicapai dalam permainan tangram ini siswa mampu berpikir kritis, cermat dan bekerja keras.

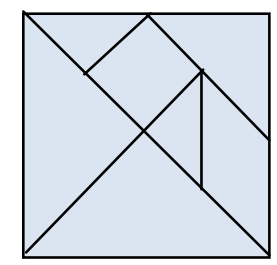

Gambar 2. Tangram

72 Suska Journal of Mathematics Education Vol.1, No.1, 2015 
Permainan yang menggunakan aturan, tahap ini merupakan tahap belajar konsep setelah di dalam periode tertentu permainan bebas terlaksana Di dalam tahap ini peserta didik mulai meneliti pola-pola dan keteraturan yang terdapat di dalam konsep itu. Permainan yang disertai dengan aturan tertentu dapat membantu siswa dalam konsep dan melatih berpikir matematik. Untuk lebih jelasnya, berikut ini diberikan contoh beserta penjelasannya.

4) Permainan Menyusun Angka-angka.

Perhatikan Gambar 3 berikut :

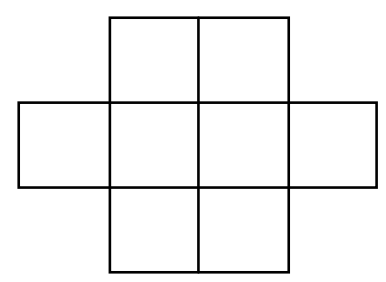

Gambar 3. Permainan Menyusun

Angka-angka Aturan permainannya sebagai berikut :

Masukkanlah semua angka angka 1,2,3,4,5,6,7,8 kedalam kotak-kotak Gambar 3sedemikian rupa sehingga selisih dua kotak yang berdekatan harus kurang dari satu.Dalam permainan ini, kalau siswa langsung saja mencoba mengerjakannya tanpa sedikit berpikir konsep matematika maka akan memakan waktu yang akan lama, sebab hanya menggunakan coba-coba saja, sebaliknya jika menggunakan konsep peluang maka akan cepat terjawab.

Permainan ini dapat dikaitkan dengan materi teori kemungkinan.Permainan ini dapat diberikan pada siswa SMP, SMU maupun untuk umum, penalaran yang dapat ditunjang yaitu berpikir kritis, cermat dan kerja keras.

5) Permainan menyusun angka lainnya seperti menyusun bilangan dari angka $1 \mathrm{~s} / \mathrm{d} 9$ ke dalam kotak berukuran $3 \times 3$ (3 baris 3 kolom) sehingga jumlah setiap baris, tiap kolom dan setiap diagonalnya harus sama, yaitu 15.

$\begin{array}{lll}8 & 1 & 6 \\ 3 & 5 & 7 \\ 4 & 9 & 2\end{array}$

6) Permainan perkalian petani Rusia

Cara perkalian ini dipergunakan oleh petani Rusia pada beratus tahun yang lampau sampai akhir abad "Renaisance". Mungkin pada waktu sekarang 
petani Rusia sendiri tidak mengenal lagi cara ini. Cara ini lebih mudah dipakai sebab hanya menggunakan pengertian "setengahnya" dan "penduakalian". Perlu diingat bahwa beratus-ratus tahun yang lampau soalsoal perkalian itu merupakan hal yang sukar.

Cara ini dpakai untuk mengalikan 2 bilangan. Yang pertama dengan dua dan membagi bilangan yang kedua dengan dua. Sisa dari pembagian itu diabaikan. Pengerjaan itu selesai bila bilangan yang dibagi menjadi 1. Contoh $45 \times 64$

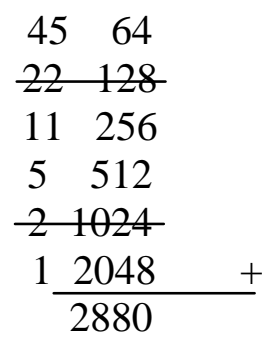

Langkah-langkah yang dilakukan adalah:

a) Tulis 45 dan 64 di atas

b) Bagi dua 45 diperoleh 22 (sisanya diabaikan). Kalikan 64 dengan 2 diperoleh 128. Tulis 22 dibawah 45 dan 128 dibawah 64.

c) Bagi 22 dengan 2 diperoleh 11. Tulis 11 dibawah 22. Lalu kalkan 128 dengan 2 diperoleh 256. Tulis 256 dibawah 128.

d) Dan seterusnya, sehingga bilangan yang dibagi 2 terus menerus menjadi 1 .

e) Corenglah bilangan-bilangan pada kolom yang dikalikan yang letaknya sejajar dengan bilangan-bilangan genap pada kolom bilangan yang dibagi (pada contoh di atas 128 letaknya sejajar dengan 22 dan 1024 sejajar dengan 2; jadi corenglah 128 dan 1024.

f) Jumlahkanlah bilangan-bilangan yang ada pada kolom di sebelah kanan itu (kecuali yang sudah di coreng). Maka pada contoh di atas $64+256+512+2048=2880$. Maka $45 \times 64=2880$.

\section{Seni Matematika dalam Pembelajaran}

Dalam pembelajaran matematika dikelas tentunya seni bermatematika perlu diciptakan oleh guru. Namun demikian, memang tidak semua materi matematika dapat disajikan dalam bentuk seni maupun permainan matematika. Seni bermatematika membutuhkan pemikiran dan kemauan serta kreatifitas guru dalam mengolahnya. Agar pelajaran matematika tidak terkesan sulit oleh peserta didik, maka guru harus ada usaha menyampaikan 
aktivitas matematika bersamaan saat menyajikan suatu topik matematika tertentu.

Beberapa alternatif menyajkan seni matematika antara lain dalam matematika, guru dapat menyampaikan hal istimewa (seni matematika) dalam mengoperasikan bilangan. Misalnya teknik melakukan perkalian atau Pembagian dengan cepat, bagaimana menghitung suatu bilangan habis dibagi oleh bilangan lainnya dan sebagainya, seperti pada soal cerita, teka-teki dan permainan menyusun angka di atas. Somakin (1997) menjelaskan bahwa dalam setiap mengajarkan materi, sebaiknya guru mengupayakan saat menjelang akhir jam pelajaran memberikan salah satu contoh teka-teki, atau seni matematika yang dapat menarik siswa yang tentunya relevan dengan materi yang dipelajari. Misalnya, pada saat menyajikan topik geometri datar, diberikan permainan tangram, pentamino-pentamino. Dalam mengajarkan suatu materi matematika guru sedapat mungkin dapat menyampaikan kaitan pemakaian materi tersebut di dalam kehidupan sehari-hari.

\section{PENUTUP}

\section{Kesimpulan}

1. Pelajaran matematika sebenarnya tidak sulit, apabila dapat disajikan dalam bentuk yang mudah, menarik dan menyenangkan sehingga mudah dipahami oleh anak didik.

2. Seni keindahan dalam pengajaran matematika dapat meningkatkan minat anak terhadap pelajaran matematika, khususnya dalam mengungkapkan seni matematika dalam bentuk cerita, teka-teki, permainan juga manfaat matematika dalam kehidupan sehari-hari.

3. Guru matematika sebaiknya dapat menambah wawasan matematikanya itu sendiri melalui serangkaian uji coba di kelasnya sendiri.

\section{Saran}

1. Dalam penulisan makalah ini, pembaca dapat menindak lanjuti dengan menerapakan beberapa cara yang disajikan di atas dalam pembelajaran matematika, sehingga dapat menghasilkan pembelajaran yang menarik dan menyenangkan.

2. Untuk efektifitasnya dapat di telaah lebih lanjut menjadi sebuah kajian penelitian secara empiris dengan menggunakan berbagai pendekatan, metode pembelajaran matematika dan metode penelitian.

3. Keindahan matematika masih banyak yang belum dapat di ungkapkan oleh penulis. Keindahan matematika dapat ditelaah lebih lanjut untuk tiap bidang seperti khusus keindahan dalam aljabar, keindahan dalam 
geometri, keindahan dalam kalkulus, keindahan dalam statistik, dan sebagainya.

4. Perlu juga dikembangkan bahan ajar khusus pegangan guru matematika tentang seni bermatematika pada matematika sekolah, baik untuk matematika sekolah SD, SMP dan SMA.

\section{DAFTAR PUSTAKA}

Dimas, A. (2012). Matematika dan Keindahan, [Online]. Tersedia : http://dimasadji4.wordpress.com/2012/10/20/matematika-dan-keindahan/

Faribarca. (2012). Matematika Sebagai Seni. [Online]. Tersedia : http://feribarca.blogspot.com/2012/04/matematika-sebagai-seni.html

Hudojo, H. (1988). Mengajar Belajar Matematika. Depdikbud: Jakarta.

Johnson dan Rising. (1972). Matematika sebagai Seni. [Online]. Tersedia : http://feribarca.blogspot.com/2012/04/matematika-sebagai-seni.html.

Ruseffendi, E.T. (2010) Dasar-Dasar Matematika Modern dan Komputer untuk Guru. Bandung: Tarsito.

Sardiman, A.M. (2006). Interaksi \& Motivasi Belajar mengajar. Jakarta : PT. Raja Grafindo Persada

Soehakso. (2012). Keindahan Matematika.[Online]. Tersedia : http://p4tkmatematika.org/2012/04/keindahan-matematika/

Soedjadi, R. (1992). Meningkatkan Minat Siswa Terhadap Matematika.Surabaya: Media Pendidikan dan Ilmu Pengetahuan.

. (1994). Memantapkan Matematika Sekolah Sebagai Wahana Pendidikan dan Pembudayaan Penalaran. Surabaya: Media Pendidikan Matematika Nasional.

Somakin, (1997).Jurnal kependidikan, Tahun XVI. Unsur Seni dalam Pembelajaran Matematika Sriyanto. (2007). Strategi sukses menguasai Matematika. Jakarta: PT. Buku Kita.

Sriyanto. (2007). Strategi Sukses Menguasai Matematika. Jakarta : PT. Buku Kita.

TIM MKPBM . (2001). Strategi Pembelajaran Matematika Kontemporer. Bandung : FMIPA UPI Bandung

Widodo. (2012). Keindahan Matematika. Yogyakarta : PPPPTK Matematika 